\title{
Formação, sustentação ou implosão de uma bolha imobiliária? A dinâmica de preços no mercado de imóveis de Natal no período $2005-2010^{*}$
}

\author{
Márcia Maria de O. Bezerra ** \\ André Luíz Correa ${ }^{* * *}$ \\ Ana Rosa Ribeiro de Mendonça ${ }^{* * * *}$ \\ Maria do Livramento Miranda Clementino ${ }^{* * * * *}$
}

\begin{abstract}
Resumo
A motivação para a realização deste artigo foi a percepção de que o movimento de preços dos imóveis em Natal apresentava componentes que precisavam ser investigados, notadamente o influxo de capital estrangeiro, sobretudo para aplicação nos setores de turismo e imobiliário e o comportamento do crédito imobiliário. O objetivo do trabalho é examinar a evolução dos preços no mercado de imóveis da cidade no período 2005-2010. Os indicadores levantados permitiram uma coleta de evidências suficiente para ampliar o grau de confiança nas hipóteses de que, de fato: a) ocorreu uma bolha no mercado de imóveis no triênio 2005-2007; b) a bolha não implodiu no biênio 2009-2010, após a crise financeira de 2008, pois o movimento de alta de preços se manteve tanto nos imóveis vendidos na planta quanto nos imóveis prontos.
\end{abstract}

Palavras-chave: Bolha imobiliária; Capital estrangeiro; Crédito imobiliário

\section{Abstract \\ Development, maintenance or implosion of a housing bubble? The dynamics of prices on Natal's real estate market in the period 2005-2010}

This paper was motivated by the perception that the rising of house prices in Natal had components that needed to be investigated, among them, the foreign capital influx, especially for application in the sectors of tourism and real estate, and the behavior of mortgage. The aim of this work is to examine the evolution of market prices of properties in the city during the period 2005-2010. The indicators presented allowed a collection of evidences sufficient to show that: a) there was a bubble in real estate in the triennium 2005-2007; b) this bubble was not imploded in 2009-2010, after the 2008 financial crisis, as the upward movement of prices remained.

* Trabalho recebido em 8 de abril de 2010 e aprovado em 12 de maio de 2012. Os autores reconhecem o apoio financeiro dado pelo CNPQ e o trabalho de coleta de dados dos bolsistas à época, Elaine Carvalho de Lima e José Duarte Barbosa Júnior. Agradecem também aos dois pareceristas anônimos desta revista, eximindo-os de eventuais falhas remanescentes.

${ }^{* *}$ Professora Doutora do Departamento de Economia da Universidade Federal do Rio Grande do Norte (UFRN), Natal, RN, Brasil. E-mail: marciabezerra@ufrnet.br.

**** Professor Doutor da Universidade Estadual Paulista (Unesp), Araraquara, SP, Brasil. E-mail: andrelc@fclar.unesp.br.

**** Professora Doutora do Instituto de Economia da Universidade Estadual de Campinas (IE/Unicamp), Campinas, SP, Brasil. E-mail: arrm@eco.unicamp.br.

***** Professora Doutora do Departamento de Políticas Públicas da Universidade Federal do Rio Grande do Norte (UFRN), Natal, RN, Brasil. E-mail: clement@ufrnet.br. 
Keywords: Real state bubbles; Foreign capital; Real state credit.

JEL R 32, F39, R39.

\section{Introdução}

Kindleberger (2000), ao ressaltar que diferentes ativos serviram de objeto de especulação ao longo do tempo, destaca casos de aplicações em terras, prédios de escritório, centros comerciais, condomínios e casas, que se tornaram verdadeiras manias em certas ocasiões. A literatura econômica pode fornecer evidências de movimentos especulativos recentes, a exemplo de imóveis em países como Japão (anos oitenta) e Estados Unidos (grande parte da década passada), que, por sua intensidade, configuram exemplos das chamadas bolhas imobiliárias ${ }^{1}$.

O movimento especulativo com imóveis na última década não ficou restrito aos Estados Unidos, mas se estendeu a outros países centrais e incorporou, em maior ou menor grau, países em desenvolvimento. A propagação desse fenômeno em escala mundial foi sustentada, em parte, pela elevada liquidez internacional, alimentada pela política monetária americana, que manteve baixas taxas de juros durante grande parte do período, e pela redução das barreiras à mobilidade de capitais ensejada pelos processos de desregulamentação e abertura financeira observados em vários países.

A emergência do boom imobiliário em alguns países manteve estreita conexão com os negócios turísticos, tendo sido provocada, sobretudo, pelo elevado índice de construção de novos empreendimentos, cujo público-alvo eram turistas estrangeiros. Pode-se citar, como referência, o que aconteceu em determinadas regiões da Espanha, em alguns países do sudoeste asiático e, mesmo recentemente, em áreas do território brasileiro, a exemplo do litoral nordestino. Muitos desses turistas combinavam interesses de aplicação com os de constituir uma segunda residência nessas destinações. O litoral do Rio Grande do Norte, notadamente a capital do estado, Natal, atraiu diversos visitantes que realizaram esse propósito, o que contribuiu para aquecer o mercado de imóveis local e tornar comum a presença conjunta de empresários da construção civil e agentes imobiliários que operavam na cidade e nas grandes feiras de turismo da Europa. As agências de viagem, por sua vez, inovaram seus procedimentos, mantendo, frequentemente, escritórios imobiliários em suas instalações.

Os primeiros investidores com capital estrangeiro com vistas à aquisição de imóveis na cidade eram turistas. Todavia, a intensidade da procura despertou o interesse de agentes imobiliários de seus países de origem e mesmo de algumas grandes incorporadoras, que passaram a operar na cidade associando-se às empresas locais em função das restrições legais existentes à época. O aquecimento do mercado imobiliário de Natal atraiu também empresas do setor que operavam

(1) Dimsky (2004), Vidotto (2008) e Macedo e Silva (2006). 
no Centro-Sul do país. Em concomitância a essa efervescência do setor turístico e imobiliário, os jornais da cidade publicaram várias matérias sobre a disparada de preços dos terrenos e imóveis transacionados e a escalada de novos empreendimentos voltados para a construção de imóveis verticais.

Contudo, o estouro da bolha americana em 2008 e as crises financeira e econômica que atingiram os países europeus reduziram o número de visitantes estrangeiros assim como sua procura por imóveis na cidade. Algumas incorporadoras estrangeiras atingidas pela crise paralisaram suas operações no estado, enquanto empresas locais, incluindo afiliadas a firmas estrangeiras e nacionais de capital aberto radicadas no Centro-Sul do país, reorientaram seus produtos imobiliários, visando o comprador doméstico, fenômeno que foi facilitado pelo aumento substancial da oferta de crédito imobiliário nesse período, sobretudo após a crise de 2008 .

Este artigo pretende construir indicadores que permitam averiguar se houve formação de bolha nos preços praticados no mercado imobiliário residencial de construções verticais em Natal no período 2005-2007 e implosão após a crise de 2008. Procura verificar, ainda, se houve queda de preços no biênio 2009-2010.

O estudo está estruturado em torno das seguintes hipóteses: a) o aquecimento dos mercados primários e secundários de imóveis residenciais de construção vertical em Natal no período 2005-2007 configura tipicamente uma situação de bolha imobiliária; b) a bolha não implodiu no biênio 2009-2010, após a crise financeira de 2008, pois o movimento de alta de preços se manteve tanto em relação aos imóveis na planta quanto aos imóveis prontos.

\section{$1 \mathrm{O}$ fenômeno das bolhas imobiliárias}

A literatura sobre bolhas de ativos revela que esse é um tema que enseja desafios tanto no campo ortodoxo quanto na heterodoxia. Na visão convencional, existe bolha quando o preço de equilíbrio de um ativo se desvia dos fatores determinantes de seus fundamentos ${ }^{2}$. Sua consideração aponta para três aspectos fundamentais: i) trata-se de fenômeno compatível com a hipótese de expectativas racionais (bolhas racionais); ii) pode existir em condições excepcionais, mas, se e quando ocorre, amplia a eficiência dinâmica dos mercados de capitais (bolhas em modelos de equilíbrio geral) (Blanchard; Fisher, 1989, cap. 5); e iii) os modelos de mercados eficientes (bolhas em paradigmas de mercados eficientes) ${ }^{3}$ podem ser passíveis de questionamento.

(2) A consideração de sua ocorrência implica o reconhecimento de um "comportamento especulativo" com efeitos sobre a determinação de preços desses ativos (Black, 2002).

(3) Canuto e Laplane (1995) mencionam modelos que procuram compatibilizar o tratamento das bolhas com as hipóteses de mercados eficientes e de expectativas racionais. É possível, no entanto, encontrar em Oreiro (2004) referência ao trabalho de Azaríads (1993), que contesta a possibilidade de sustentação da hipótese de eficiência dos mercados com ocorrência de bolhas. 
As teorias das bolhas racionais receberam críticas a respeito de sua reduzida capacidade de "aplicação ao mundo real", ao fato de "não ter nada a dizer sobre a emergência das bolhas", bem como ao estabelecimento que fazem a priori de uma relação de independência entre os fatores explicativos do valor fundamental do ativo e os determinantes do componente especulativo do mesmo (bolha). Como observam Canuto e Laplane (1995, p. 42), "a especulação continua um corpo estranho no mundo das expectativas racionais". Esse incômodo aparente, que não surpreende e se manifesta na posição da literatura heterodoxa sobre o assunto, transbordou inclusive para manuais afeitos à visão convencional, como o de Miles e Sott (2005) ${ }^{4}$.

No campo da heterodoxia, o tratamento de bolhas de ativos também requer cautela, especialmente para os que partilham do princípio da incerteza proposto por Keynes, que, entre outros aspectos, considera que o estado de confiança dos agentes em suas previsões pode mudar. Assim, para Dymski (1998, p. 83), "tornase difícil caracterizar 'bolhas' porque a linha que separa investimentos sólidos dos frágeis é inconstante e mutável ao longo do tempo". O autor observa também que as tomadas de decisão dos agentes podem ser sustentadas em "estruturas institucionais" geradas por meio de "convenções comportamentais" que "se desenrolam dentro de cenários estruturais agregados, que tanto dão formas às dinâmicas econômicas como estabelecem limites aos resultados compatíveis" (1998, p. 84). Contudo, as mesmas convenções que promovem a "estabilidade condicional" em determinado período geram "consequências comportamentais" responsáveis pela corrosão da "aparente estabilidade".

É nessa perspectiva que Dymski enxerga a possibilidade de tratamento de ciclos econômicos com estruturas conceituais capazes de explicar o surgimento de bolhas de ativos (e sua ruptura), a exemplo do modelo minskyano. A bolha de ativos poderia ser explicada a partir da relação entre os preços de mercado $\left(\mathrm{P}^{\mathrm{k}}\right)$ e os custos de produção $\left(\mathrm{P}^{\mathrm{I}}\right)$, refletindo mudanças nos balanços patrimoniais provocadas pelo aumento da fragilidade financeira dos agentes durante as fases de expansão nas quais o setor bancário teria um papel importante. Assim, segundo Dymski (2004, p. 407), “à medida que avança o período de expansão, vai surgindo uma bolha de ativos: especificamente, a bolha aparece quando a razão $\mathrm{P}^{\mathrm{k}} / \mathrm{P}^{\mathrm{I}}$ é maior que um durante um tempo prolongado".

Mas outras possibilidades para o tratamento de bolhas de ativos devem ser exploradas, e sua abordagem pode ser pensada mesmo no contexto de equilíbrio do capítulo 17 da Teoria Geral de Keynes, que é suficientemente fecundo para permitir a análise desse fenômeno. Nesse capítulo, Keynes explica que a demanda

(4) "Muitos enigmas sobre o preço do mercado das ações e alterações nos retornos são difíceis de ser conciliados com a visão de que os preços são o valor descontado de ganhos futuros esperados e também de que as pessoas formam expectativas racionais e coerentes" (Miles; Scott, 2005, p. 447). 
por cada classe de ativos tem por base a consideração dos seguintes atributos: a geração de renda que sua posse pode proporcionar (lucros, juros, dividendos, aluguéis, etc.), q; o custo de manutenção esperado associado à retenção do ativo, c; o prêmio de liquidez, 1; e a apreciação ou depreciação esperada em seus valores de mercado, a; todos eles "medidos por um quociente em que o denominador é o preço spot corrente do ativo". Desse modo, a taxa de retorno esperada de cada ativo seria dada por $\mathrm{a}+\mathrm{q}-\mathrm{c}+1$. (Carvalho, 2007, p. 5-6).

O tratamento de bolhas não parece ser incompatível com a estrutura do capítulo 17 da Teoria Geral, desde que seja introduzida uma hipótese adicional que pressuponha o surgimento de um mecanismo de interação entre o atributo "a" e o preço do ativo. A condição para que haja bolha é que a expectativa de valorização, medida por esse atributo, responda ao aumento do preço corrente. Assim, uma elevação inicial em "a" promove inicialmente um aumento da taxa de retorno do ativo e acarreta a expansão de sua demanda com impacto positivo sobre seu preço. Pode-se supor, adicionalmente, que o consequente incremento nos preços alimente expectativas de novos aumentos, afetando mais uma vez "a" e disparando outro processo de retroalimentação. Nesse caso, pode-se pensar em emergência de bolhas no contexto de taxas de retorno de equilíbrio entre os diferentes ativos, desde que o citado mecanismo de interação opere alimentando fortemente as expectativas sucessivas de subida de preço. O conceito adequado para medir a intensidade da realimentação das expectativas sobre os preços é o de elasticidade das expectativas de Hicks (1939).

Davidson (1978), em sua estrutura analítica, oferece indicações interessantes para se avaliar a gestação de bolhas imobiliárias. $\mathrm{O}$ autor analisa em profundidade os componentes do atributo "a", identificando, a partir de suas variáveis, preços forward e spot e mecanismos indutores das decisões de aplicação dos agentes. De fato, Davidson construiu uma teoria a respeito de como o funcionamento dos mercados spot e forward afeta as decisões dos agentes e, por conseguinte, o desempenho da economia por meio de seus respectivos preços. Nessa perspectiva, o mercado spot se evidencia quando o preço correspondente permite alocar o estoque de uma mercadoria disponível resultante de períodos de produção anteriores, de modo que não haja excesso de oferta e de demanda. No mercado forward, deve haver alteração na quantidade produzida de um bem para entrega futura com vistas a atender os termos dos contratos celebrados com os compradores; o preço forward também pode ser considerado como o preço do fluxo de oferta do período curto ${ }^{5}$.

Através dos preços forward e spot, Davidson examina os mecanismos de estímulo à produção e seus efeitos sobre os preços, sugerindo que, em se tratando de um período curto, o preço spot seja considerado o preço do período de mercado

(5) Período curto "é a unidade de tempo relevante à valorização do capital", compreendendo o período de produção e o período de mercado (Macedo e Silva, 1999, p. 77). 
e o preço forward "o preço que o empresário considera no início do período de produção". Desse modo, o comportamento da demanda tem impacto sobre o nível de estoques e sobre o preço spot, e a comparação entre este último preço e o preço forward serve de base para que o empresário tome sua decisão de produção ${ }^{6}$. Assim, quando o preço spot supera o preço forward, a diferença entre os mesmos induz a 'recomposição de estoques' (situação de backwardation), mas, quando o preço forward é superior ao spot, a elevação dos níveis de estoques, fruto de uma demanda insuficiente, tende a "desestimular a produção" (situação de contango no mercado).

Davidson observa que os arranjos institucionais que sustentam os mercados spot e forward em algumas economias capitalistas desenvolvidas encorajam a especulação com diferentes tipos de ativos (Davidson, 1978, p. 108). Nesse sentido, os próprios mecanismos de preço spot e forward podem servir de indicadores do grau de atração que determinados ativos representam para os aplicadores em busca de maiores taxas de retorno: quando muito elevados, podem ser vistos como um dos elementos que favorecem o movimento de especulação.. De fato, o autor assume que a especulação só tem lugar em um mundo incerto "onde mudanças nos fatores subjacentes à relação de oferta e demanda não podem nunca ser antecipadas com certeza". O especulador supõe que pode "antever eventos futuros melhor que a melhor estimativa que o mercado pode fazer com a informação disponível corrente" (Davidson, 1978, p. 108).

Para além da perspectiva pós-keynesiana, outro autor que pode dar suporte à temática tratada é Tobin (1969), inclusive por fornecer elementos para a construção de indicadores adequados à investigação de bolhas imobiliárias. Seu modelo analisa os canais pelos quais a política monetária pode afetar o investimento, considerando os dois preços: $\mathrm{Pk}$, que representa o preço do capital preexistente (índice de preço das ações), e P, que corresponde ao preço dos bens de capital novo (índice geral de preços para a economia inteira). Assim, o "q" de Tobin é dado pelo coeficiente $\mathrm{Pk} / \mathrm{P}^{7}$.

Além dos efeitos da política monetária sobre os investimentos, o modelo de Tobin permite extrair o seguinte resultado: a especulação financeira, ao afetar o nível de preços dos ativos, tem impacto sobre os gastos com investimentos e a demanda agregada, "contaminando", portanto, a determinação dos níveis de produção, renda real e emprego. O movimento especulativo em torno de ações cuja

(6) A decisão de investimento, por sua vez, requer que o empresário estabeleça uma análise comparativa entre o preço forward e o preço do fluxo de oferta no longo prazo (no sentido microeconômico, que significa a variação na capacidade produtiva).

(7) Quando q agregado é maior que $1(\mathrm{Pk}>\mathrm{P})$, o mecanismo de preços opera no sentido de incentivar a construção de novas empresas e/ou expandir as plantas que já estão em operação, desestimulando a aquisição de firmas preexistentes no mercado acionário. Se q é menor que $1(\mathrm{Pk}<\mathrm{P})$, o sistema de preços incentiva a compra de empresas estabelecidas no mercado acionário, pois torna relativamente mais cara a construção de novas firmas ou a expansão de plantas já em operação. 
oferta é inelástica no curto prazo tende a elevar seus preços, muito sensíveis à demanda, e, nesses termos, aumentar os gastos com investimentos, expandindo a demanda agregada, a produção, o emprego e a renda real. Tal processo, ao realimentar a demanda por ações, ocasiona novas subidas de preços, e sua continuação por períodos sucessivos pode levar à formação de bolhas especulativas $^{8}$.

Com base no modelo de Tobin, é possível observar que, no mercado de imóveis, opera um mecanismo similar ao descrito no caso das ações. Assim como estes últimos ativos, os imóveis apresentam oferta inelástica no curto prazo por serem relativamente longos os períodos de produção associados à sua construção e seus preços muito sensíveis à demanda. Portanto, se o coeficiente "q" é superior a 1, configura-se a indicação de ocorrência de boom no mercado imobiliário, e, quando muito superior, representa um indicador de bolha 9 .

A abordagem da temática bolha de ativos suscita outra questão analisada em profundidade por Dymski (1998, 2004), qual seja, sua ocorrência se dá em um determinado espaço, em uma "economia limitada por fronteira"10. Para o autor, "o traço estrutural essencial das bolhas de ativos é que elas são fenômenos inerentemente espaciais e temporais" (Dymski, 2004, p. 412). Essa qualificação resulta na possibilidade de outros fenômenos, além dos descritos no modelo de Minsky, explicarem a emergência de bolhas em uma dada economia: a absorção de fluxos de riqueza (internos ou internacionais) e/ou população que provoque uma pressão sobre os preços dos ativos comparativamente a seus custos reais de produção. Com base nessas considerações, Dymski analisa as situações de emergência de bolhas de ativos tanto no âmbito de países como o Japão e a Coreia como em estados específicos, a exemplo do estado da Califórnia, nos Estados Unidos. Em todos os casos analisados, os preços dos imóveis sofreram pressões

(8) De acordo com a lógica do modelo, tais processos especulativos tendem a ser revertidos, pois a arbitragem perfeita gerada pelo mecanismo de preços incentiva a demanda por bens de capital recém-construídos (pressionando seus preços para cima) e reduz a demanda por empresas preexistentes no mercado acionário (pressionando seus preços para baixo), conduzindo ao equilíbrio de longo prazo no qual se verifica a igualdade entre $\mathrm{Pk}$ e $\mathrm{P}(\mathrm{Pk}=\mathrm{P})$, de modo que $\mathrm{q}=1$.

(9) Convém esclarecer que o "q" de Tobin será considerado como um dos indicadores de possível ocorrência de bolha sem que se adote a suposição de uma tendência dos mercados a operarem em situação de equilíbrio ( $\mathrm{q}=1$ ). Neste trabalho, um desvio significativo do valor de q em relação a 1 pode ser interpretado como indício de bolha. Essa abordagem parece afinada com o modelo de dois preços de Minsky, no qual também os desvios significativos da razão $\mathrm{Pk} / \mathrm{PI}$ em relação a 1 podem ser considerados indicadores de bolha a despeito da ausência de uma tendência no sentido de equilíbrio. Em outros termos, o "q" de Tobin será usado apenas como indicador, sem que, necessariamente, seu emprego implique a aceitação das hipóteses comportamentais utilizadas por ele para a construção da teoria.

(10) Para Dymski (2004, p. 412), “o termo é propositadamente elástico; um país é uma economia limitada por fronteiras, mas também o é uma cidade desse país, um bairro dessa cidade, uma rua desse bairro e até uma casa dessa rua". 
altistas, gerando bolhas imobiliárias, cujo estouro foi seguido pelo colapso dos preços dos imóveis e por severos distúrbios financeiros.

Com base nessa perspectiva, foi realizado o estudo empírico apresentado a seguir, no sentido de examinar se houve formação de bolha imobiliária na cidade de Natal, capital do estado do Rio Grande do Norte, que, ao longo dos últimos anos, tem se firmado como polo turístico, atraindo turistas brasileiros e estrangeiros. Ademais, o estudo, cujos dados cobrem o período 2005-2010, permite identificar se os preços dos imóveis e as rendas de aluguel na cidade teriam sido negativamente afetados nos dois anos subsequentes à ruptura da bolha imobiliária americana e à crise que se seguiu em vários países, atingindo fortemente os países de origem de turistas que se dirigiam ao estado potiguar. Os índices para mensuração foram construídos com base nos indicadores elaborados a partir da bibliografia considerada nessa seção ${ }^{11}$, ou seja: 1) Indicador de preço dos imóveis (IP); Indicador de aluguel e preço (IA); e Indicador de preço e custo da construção (IC).

Conforme será visto na seção 2, o primeiro indicador (IP) é inspirado em Davidson. A seção 3 explica porque esse indicador deve ser comparado a uma taxa de juros de referência, enquanto o terceiro indicador (IC) tem por base "q" de Tobin. A seção seguinte tem o propósito, na medida em que um trabalho empírico permite, de incorporar, à análise da temática tratada, aspectos históricos e institucionais que podem contribuir para explicar a evolução do mercado imobiliário em Natal no período de análise.

\section{Condicionantes da evolução do mercado imobiliário de Natal}

A análise dos fatores condicionantes do setor imobiliário de Natal comporta diferentes níveis de abstração. Inicialmente, em um nível de abstração mais elevado, devem ser identificadas as características desse mercado para examinar se configura a existência de mercados spot e forward. No mesmo tópico, mas com menor nível de abstração, são examinados aspectos referentes ao marco regulatório com o qual o poder público discrimina o uso do solo e define o grau de escassez do insumo básico à construção, ou seja, os terrenos disponíveis. Em seguida, são tratadas as conexões entre o desenvolvimento dos negócios turísticos e imobiliários que ensejaram a atração de investimentos estrangeiros no estado do Rio Grande do Norte na segunda metade da década passada. Por fim, como a construção e demanda por imóveis costumam também ser afetadas pelo

(11) Convém salientar que a abordagem da literatura considerada nessa seção privilegiou questões de interesse da temática tratada. Para uma descrição do fenômeno da bolha em termos do que tende a acontecer e sequência de fenômenos coerente com as noções de tempo histórico e incerteza keynesiana, ver Kindleberger (2000, cap.2) e Dymski (1998). 
comportamento do crédito, o desempenho do mercado de crédito imobiliário será objeto de exame no sentido de verificar se houve favorecimento ou desestímulo à construção de imóveis na cidade.

\subsection{Mercados spot e forward e marcos regulatórios no setor imobiliário}

Com relação ao primeiro fator condicionante, a literatura de referência remete-se a Davidson (1978). O autor estabelece os seguintes requisitos para que um ativo apresente mercados spot e forward bem organizados: i) ampla demanda; ii) padronização; iii) elevado grau de substitutibilidade "entre velhos e novos itens"; iv) fluxo anual de oferta pequeno quando comparado ao volume de estoque existente; v) durabilidade; e vi) "ser valorizado em proporção ao seu volume". Davidson (1978, p. 94) observa, contudo, que o desenvolvimento dos mercados spot e forward está condicionado a determinadas características, ou seja, que o fluxo anual de produção represente uma pequena proporção do estoque de bens existentes e que esse bem seja durável. As demais características seriam condições essenciais para que esses mercados se tornassem bem organizados e perfeitos, incluindo a existência de uma instituição que operasse como comprador e vendedor residual no mercado

Com base em Davidson, é possível constatar que os imóveis negociados em grandes áreas urbanas atendem aos requisitos para o desenvolvimento dos mercados spot e forward, pois constituem "bens duráveis", cujo fluxo de produção em determinado período representa parcela pouco expressiva do total de estoque de imóveis existentes. Ademais, os arranjos institucionais sobre os quais se assentam as condições de oferta e demanda visam garantir a existência dos dois mercados: as operações de incorporação, com a consequente contratação das atividades de construção civil, representam o espaço institucional para o estabelecimento de uma proxy de mercado forward ${ }^{12}$, enquanto as empresas imobiliárias, que operam como um canal de distribuição ao atuarem na venda de lançamentos imobiliários (venda de imóveis na planta) e na comercialização de imóveis no mercado secundário (imóveis de terceiros), contribuem para aprofundar tais mercados, inclusive por prestarem serviços de locação.

(12) As empresas incorporadoras costumam planejar os empreendimentos imobiliários; negociam a compra de terrenos dos proprietários fundiários e assumem a responsabilidade pelos custos associados ao processo de incorporação, que envolve o custo de financiamento da construção. A empresa da construção civil que formaliza um contrato de construção e de entrega de imóveis ao incorporador opera com um preço estabelecido tipicamente em mercados forward. Nos períodos de intenso crescimento, na fase de boom imobiliário, os níveis de preços dos imóveis e a disponibilidade de crédito podem fornecer estímulo para que as empresas da construção civil procedam à verticalização de suas atividades e operem no segmento de incorporação. 
Nesse sentido, embora considerando a existência de mercados spot e forward para os ativos imobiliários, a ausência das demais características impede que os mesmos tenham a profundidade e a liquidez necessárias para torná-los perfeitos. Ressalta-se, sobretudo, a inexistência de uma instituição que opere como market maker, ou seja, que atue como estabilizador de mercado, evitando que os preços dos imóveis disparem (ao intervir, vendendo as unidades necessárias para satisfazer a demanda adicional) ou declinem (ao operar, comprando quando a oferta desses bens no mercado é excessiva).

Como tratado na primeira seção, o modelo de Davidson sugere a possibilidade de as bolhas serem descritas por meio de uma peculiar interação entre a oferta e a demanda de ativos que se reflete na relação entre seus preços spot e forward. Aplicando esse modelo ao mercado imobiliário, a relação a ser considerada deve ser preço do imóvel à vista (preço spot) nos mercados primários e preço do imóvel na planta. A ausência de um mercado futuro organizado de imóveis no município de Natal, pode ser superada, para efeito de análise, pela suposição de que o lançamento do imóvel na planta seja uma proxy do mercado forward. Com relação à questão da heterogeneidade do ativo imobiliário, uma forma de contorná-la seria considerar a construção de imóveis com características relativamente próximas, a exemplo dos imóveis verticais, cuja padronização mínima pode ser considerada quando se leva em conta a área construída e o bairro em que se localiza.

Empregando a mesma terminologia utilizada por Davidson, pode-se afirmar que, quando o preço do imóvel à vista supera o preço do imóvel na planta, cria-se uma situação de backwardation, gerando um incentivo à produção de imóveis para entrega à vista. Ressalta-se que uma diferença muito elevada entre os dois preços pode evidenciar a existência de bolha. Contudo, se, ao contrário, o preço do imóvel na planta é maior que o preço à vista no mercado primário (por exemplo, devido a uma forte queda da demanda por imóveis à vista resultante de uma crise financeira ou mesmo de uma percepção generalizada de que o movimento de alta especulativa se esgotou), há uma situação de contango. O estouro de uma bolha imobiliária tende a gerar tal situação, desestimulando a produção de novos imóveis.

O exame dos fatores condicionantes à evolução do mercado imobiliário requer que se considere (em um nível de abstração menor) o papel das instituições que regulamentam a forma de ocupação do território, já que as restrições regulatórias sobre algumas áreas e as políticas de incorporação de novos espaços urbanos - proporcionados pela provisão de infraestrutura nos mesmos - também influenciam a disponibilidade de terrenos apropriados à construção. Como os 
novos terrenos são pré-requisitos indispensáveis à edificação dos imóveis e, por natureza, não reprodutíveis, a oferta dos mesmos condiciona o fluxo de produção de novos produtos imobiliários. Nesse sentido, parece razoável supor que as instituições, com seus regulamentos urbanísticos, em muitos casos sob amparo da legislação ambiental, podem operar no sentido de contribuir para o aumento ou redução da escassez de imóveis no mercado, especialmente em um contexto de forte crescimento da demanda ${ }^{13}$.

As questões institucionais relacionadas ao marco regulatório são particularmente relevantes em Natal devido ao fato de o município ter uma área total inferior a $200 \mathrm{~km}^{2}$, o que o situa como um dos menores do país. Ademais, possui uma elevada proporção de áreas não edificáveis, constituídas por terrenos pertencentes às Forças Armadas (Exército, Marinha e Aeronáutica) ou destinados à conservação ambiental, estabelecida em lei. Como exemplo deste último caso, pode ser citado o Parque das Dunas, que ocupa 15\% da cidade, bem como as áreas de mangue. A perspectiva por parte do setor público de regular o crescimento da cidade se expressa por meio da adoção de instrumentos urbanos em seu Plano Diretor, tais como a densidade de adensamento residencial de área, o coeficiente de aproveitamento máximo e a 'Outorga Onerosa'14. Convém ressaltar que questões relacionadas à regulação do crescimento despontaram no período em análise e geraram forte polêmica: em 2005, a saturação prematura do esgotamento sanitário em Ponta Negra $^{15}$ devido à demanda excessiva gerada pelos hotéis instalados na via costeira e pelos empreendimentos imobiliários recentemente implantados aumentou o controle da Secretaria Municipal de Urbanismo e Meio Ambiente (Semurb) em relação à concessão de alvarás, contribuindo para elevar o estoque de pedidos em tramitação. A Zona Norte da cidade, identificada pelos incorporadores como uma das mais importantes fronteiras de expansão do mercado imobiliário, teve seu crescimento regulado pela prefeitura em meados da década. Outras

(13) A estocagem de terrenos para fins especulativos privados, ao assegurar a retenção de espaços vazios fora do mercado, também contribuiu para aumentar a escassez de terras durante a fase de crescimento da urbanização (Ribeiro, 1997). Os proprietários desses terrenos entendem que os custos de carregamento desses ativos, inclusive pagamento de impostos, serão compensados pelos ganhos de capital que esperam realizar quando da venda por preços supostamente mais elevados. Tal aplicação deve ser vista como parte de uma decisão de alocação de portfólio na qual o custo de oportunidade aparece como a remuneração de ativos alternativos.

(14) O adensamento residencial corresponde ao número máximo de habitantes por hectare, enquanto o coeficiente de aproveitamento máximo refere-se ao total da área de um terreno que pode ser ocupada pela construção para assegurar a permeabilidade do solo. Por outro lado, a Outorga Onerosa representa o custo que o empreendimento imobiliário irá arcar caso ultrapasse os parâmetros previstos para a construção na área, considerando que, na avaliação da prefeitura, a infraestrutura disponível está adequada aos aludidos parâmetros.

(15) O bairro de Ponta Negra guarda o principal cartão postal da cidade, o Morro do Careca. 
restrições também foram colocadas, a exemplo do gabarito dos prédios, com o propósito de impedir a construção de novos espigões ${ }^{16}$.

O aumento de preço dos terrenos pode ser um indicativo da restrição relativa de áreas para novas construções na cidade. Considerando-se que grande parte dos empreendedores imobiliários não dispõe de recursos para sustentar estoques de terra e dado que as instituições financeiras não costumam financiar a aquisição de terrenos para construção, os incorporadores costumam recorrer à permuta para evitar o desembolso de dinheiro. Tal procedimento consiste na cessão da terra em troca da propriedade de um determinado número de apartamentos, representando um percentual do valor geral de vendas do imóvel (VGV). Essa prática, ao ser frequentemente adotada pelas incorporadoras, pode servir de indicador do movimento de preços dos terrenos no período considerado. A permuta, que historicamente se situava entre $10 \%$ e $12 \%$ do VGV do imóvel em Ponta Negra, atingiu o pico de 25\% em fins de 2007 com a entrada das grandes incorporadoras nacionais, alcançando um patamar próximo a $20 \%$ nos bairros mais valorizados da cidade $^{17}$.

O comportamento dos preços no bairro de Ponta Negra não foi um fenômeno aleatório e isolado, mas parte de um movimento mais amplo que deve ser investigado a partir da conexão entre o setor turístico e os negócios imobiliários. Os interesses comuns entre esses segmentos resultaram na realização, em 2006, do evento Bolsa de Oportunidades Turísticas e Imobiliárias do Rio Grande do Norte, a Bonturn, que teve sua segunda edição organizada em maio de 2008.

\subsection{Conexões entre os setores turístico e imobiliário no Rio Grande do Norte}

Há dois aspectos na associação entre os segmentos turístico e imobiliário que devem ser ressaltados: i) essa conexão ocorreu em outros estados da Região Nordeste; e ii) em algumas capitais nordestinas, houve um transbordamento dessa conexão para os imóveis residenciais. Para os propósitos deste trabalho, será tratado o caso do Rio Grande do Norte.

Entre 1996 e 2010, o fluxo de turistas para esse estado aumentou significativamente, com taxa média de crescimento anual de 11,46\%. Quando se

(16) Jornal Tribuna do Norte (18 ago. 2007).

(17) É claro que a escassez de terras pode ser relativa, tanto mais quando se compara o grau de verticalização de uma cidade como Natal com cidades como São Paulo, Rio de Janeiro e Recife, entre outras. Contudo, a questão do custo se recoloca, pois, frequentemente, a construção, para se tornar viável em termos de área já construída, vai exigir a aquisição de mais de uma casa, implicando na negociação de permuta com no mínimo dois proprietários, que podem não apresentar interesse simultâneo em se desfazer de seus respectivos imóveis em troca de promessas de propriedade sobre apartamentos a serem construídos. 
considera a procedência desses visitantes observa-se que, em termos absolutos, houve incremento tanto do número de brasileiros quanto de estrangeiros, com taxas de crescimento de $11,49 \%$ e 11,05\% a.a., respectivamente. Embora o mercado seja basicamente doméstico, a participação de estrangeiros cresceu sistematicamente até 2005, aumentando mais que o dobro em relação ao primeiro ano $\operatorname{considerado}^{18}$, embora tenha arrefecido nos anos seguintes, sobretudo após 2008, aproximando-se, então, do percentual alcançado em 1996.

Em 2007, o número total de turistas que visitou o Estado do Rio Grande do Norte, cerca de 2,2 milhões de pessoas $^{19}$, foi $170 \%$ superior ao tamanho da população da capital, em torno de 800 mil habitantes, sendo a quantidade de turistas estrangeiros equivalente a $1 / 3$ da população do município de Natal. Em 2010, a despeito do declínio do número de turistas procedentes do exterior - que correspondeu, no referido ano, a apenas $20 \%$ da população municipal -, o número de visitantes recebidos pelo estado subiu para 2,5 milhões. A evolução desse quadro denota a emergência de um turismo de massa, cuja expansão tem requerido a oferta de equipamentos e infraestrutura turísticos correspondentes, implicando a realização de investimentos significativos no setor imobiliário, também por investidores estrangeiros, sobretudo nos últimos anos.

Esse fenômeno, que ocorreu em outros estados nordestinos, foi impulsionado, no caso do Rio Grande do Norte, pelas inversões realizadas no âmbito do Prodetur $/ \mathrm{RN}^{20}$, que teve início em meados dos anos noventa, concluindo sua primeira fase em 2003. Dados registrados no Banco Central acerca do ingresso de capitais estrangeiros privados no estado revelam que o investimento externo nos setores de turismo e imobiliário cresceu de maneira expressiva ao longo dos anos 2000 independente das oscilações verificadas nos ingressos totais (Observatório das Metrópoles, 2009). O Gráfico 1 permite observar que o ápice desse movimento ocorreu em 2008, ano em que eclodiu a crise financeira internacional, intimamente associada à formação de bolhas especulativas no mercado imobiliário norte-americano. É possível verificar, nos anos de 2009 e 2010, uma redução no ingresso total de capitais, bem como na quantidade destinada aos setores de turismo e imobiliário. Não obstante, a categoria turismo e

(18) Em 1996, a participação relativa dos estrangeiros no total de turistas do Rio Grande do Norte foi cerca de $7 \%$, enquanto, em 2005 , alcançou o percentual de $17 \%$.

(19) Secretaria de Turismo do Rio Grande do Norte (2007).

(20) O Programa de Desenvolvimento do Turismo no Nordeste (Prodetur/NE) foi uma iniciativa dos governadores da região com o propósito de explorar suas potencialidades turísticas para inseri-la no circuito das grandes operadoras de turismo nacionais e internacionais. O Programa recebeu financiamento do Banco Interamericano de Desenvolvimento (BID) e do Governo Federal (através do BNDES). Em sua primeira etapa, os investimentos contemplaram as obras de infraestrutura básica, cuja carência era vista como entrave ao desenvolvimento da atividade turística e inclusive à atração de capitais privados para fomentá-la. 
imobiliário ainda representava mais de $50 \%$ do total de capitais estrangeiros privados destinados ao Rio Grande do Norte.

\section{Gráfico 1}

Evolução dos investimentos estrangeiros no Rio Grande do Norte nos anos 2000

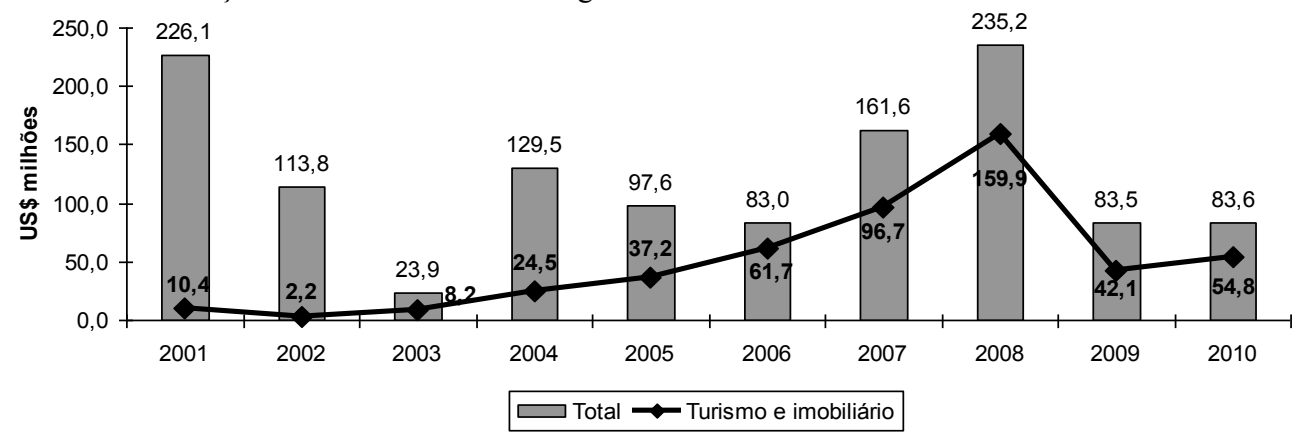

Fonte: Observatório das Metrópoles (Relatório preliminar, 2009).

Os investimentos turísticos internacionais foram dirigidos ao ramo de hotelaria, mas contemplaram outras modalidades de inversões no quesito acomodações, como a construção de apart-hotéis, condhotéis, condomínios fechados (parcelamento de uma gleba em frações condominiais horizontais), condomínios verticais, entre outros, como destaca Ferreira et al. (2009, p. 126).

Ferreira et al. (2009, p. 129) observam que $89,54 \%$ do total de investimentos estrangeiros destinados ao Rio Grande do Norte nos anos 2001-2006 eram de origem europeia, com participação de 56,41\% de Portugal e de 13,55\% da Espanha. Santos (2007, p. 47) mostra, com base nas informações da Coordenadoria Geral de Imigração do MTE, que, para o período de 2005 a setembro de 2007, o crescimento da entrada de capital estrangeiro para o setor turístico e imobiliário potiguar foi seguido de uma elevação do número de vistos concedidos para que investidores pessoas físicas operassem no estado. Em 2005, o Rio Grande do Norte posicionou-se em primeiro lugar no recebimento de estrangeiros que solicitaram entrada no país com esse tipo de autorização. No período de 2006 a setembro de 2007, ocupou a terceira posição, ficando atrás apenas do Ceará e São Paulo na concessão desses vistos.

A demanda por empreendimentos turísticos e imobiliários abrangeu grande parte da costa litorânea do Rio Grande do Norte, incluindo a capital potiguar. Como registrou o jornal de maior circulação da cidade: "Estrangeiros compravam o que viam pela frente - terrenos, casas, dezenas de apartamentos de uma só vez [...] Não se interessavam em saber se o lugar tinha infra-estrutura, se as condições de compra eram as melhores." (Jornal Tribuna do Norte, 2007). Em Natal, o bairro de Ponta Negra, que congrega grande parte da oferta hoteleira da cidade, juntamente 
com a via costeira, foi particularmente afetado pela intensa demanda estrangeira que acompanhou a forte desvalorização do real no início da década $^{21}$. Posteriormente, outros bairros do município foram incorporados nesse processo. Segundo informações de agentes do setor imobiliário da cidade, cerca de $40 \%$ da demanda por apartamentos, no período 2005-2007, era proveniente de estrangeiros, o que levou alguns desses especuladores a comprarem vários apartamentos na cidade com o propósito de revendê-los a seus concidadãos.

A ruptura da bolha imobiliária nos Estados Unidos, em 2008, ao atingir países europeus, contribuiu, no entanto, para mudar esse quadro: a demanda de estrangeiros por imóveis se restringiu, voltando a se concentrar em Ponta $\mathrm{Negra}^{22}$, embora a de nativos e migrantes tenha se mantido elevada. Essa situação provocou uma mudança no público-alvo das incorporadoras/construtoras que operavam na cidade, que passaram a visar o comprador doméstico. A análise dessa estratégia requer a observação do comportamento do crédito imobiliário, uma vez que as edificações têm preços suficientemente elevados, o que torna sua oferta e demanda sensíveis às condições de financiamento, que, por sua vez, respondem a vários determinantes gerados fora da região analisada.

\subsection{Desempenho do crédito imobiliário no período 2005-2010}

A evolução recente do financiamento habitacional no país esteve associada a determinantes mais amplos e de natureza distinta, tais como: a política macroeconômica (com impacto sobre a taxa de juros); a edição de uma série de medidas de estímulo ao segmento (de corte institucional e tributário); as estratégias adotadas por instituições financeiras na composição de sua carteira de ativos; o comportamento dos tomadores de crédito e o transbordamento da crise financeira internacional de 2007/2008. Vale notar que esta última assolou o sistema de crédito brasileiro em um momento peculiar, de importante expansão das operações. No entanto, a atuação dos bancos públicos federais nesse mercado foi fundamental para amenizar a diminuição das operações das instituições privadas. No tocante ao crédito imobiliário, após um longo período de contração do investimento residencial provocado pelo colapso do financiamento imobiliário que teve início

(21) Em reportagem publicada no Jornal Tribuna do Norte de 18 de agosto de 2007, é feita menção ao período de auge da demanda estrangeira em Ponta Negra, em que portugueses, noruegueses, italianos e espanhóis se dispunham a comprar os imóveis a serem lançados, o que assegurava, aos incorporadores, rentabilidade acima de $40 \%$.

(22) Outro aspecto que merece ser destacado é a taxa de câmbio real entre o real e o euro, que favoreceu a compra de ativos no país até meados da década. A partir de 2004, o euro sofreu um processo de depreciação (cerca de $19 \%$ em 2005 e $11 \%$ em 2006) que foi sendo amortecido até 2009 , pois, em 2010 , sua depreciação voltou ao patamar de $19 \%$. Esse processo de apreciação do real certamente contribuiu para aumentar o custo de aplicação no mercado imobiliário da cidade. 
em meados dos anos oitenta, sucedido por uma tímida recuperação em $1997^{23}$, criaram-se condições de retomada do ciclo de crescimento do crédito habitacional, em especial a partir de 2004 (Coutinho; Nascimento, 2006). Para os propósitos deste trabalho, serão considerados alguns indicadores básicos que podem esclarecer a dinâmica do crédito imobiliário no Estado do Rio Grande do Norte.

No período 2005/2010 o volume de crédito no país cresceu cerca de $110 \%$ em termos reais, o que implicou o aumento de sua participação em relação ao PIB, de $28,3 \%$ para $46,4 \%$ em $2010^{24}$. O mesmo sucedeu com o crédito habitacional procedente do Sistema Financeiro de Habitação, SFH, mais precisamente do Sistema Brasileiro de Poupança e Empréstimos, SBPE, que inclui as instituições financeiras que captam recursos por meio da caderneta poupança. O volume de financiamentos habitacionais saltou de R\$29,1 bilhões em 2005 para R\$ 103,5 bilhões no último ano do período, ressaltando-se a base muito pequena a partir da qual se deu esse crescimento.

A Tabela 1 aponta importante crescimento das operações de crédito total e habitacional no período 2005-2010, ou seja, $109,7 \%$ e $256 \%$, respectivamente. A subdivisão do período em dois, antes e depois da fragilização do sistema bancário brasileiro em função da crise internacional (2005/2008 e 2008/2010), possibilita a percepção de mudanças no movimento após a crise. Nos primeiros anos, o crédito total cresceu $65,5 \%$ e o habitacional, $78,1 \%$. No período pós crise, observou-se um arrefecimento do ritmo de crescimento do crédito total concomitante à intensificação do crescimento do habitacional. Esse movimento se refletiu no aumento da relação do crédito habitacional e total, assim como na expansão do crédito habitacional sobre o PIB, que praticamente dobrou entre 2008 e 2010. É importante destacar que, a despeito do intenso ritmo de crescimento dessas operações, tais relações ainda se mantiveram reduzidas, em especial quando comparadas com experiências internacionais. É possível aferir que, no período analisado, observou-se um crescimento do estoque de crédito, com destaque para o habitacional, movimento, este, que se intensificou nos últimos anos do período pós crise.

(23) Em 2007, foi criado o Sistema Financeiro Imobiliário (SFI), cujos financiamentos "abrangem tanto imóveis residenciais quanto comerciais, seus recursos baseiam-se na emissão de recebíveis imobiliários frutos da securitização de créditos mantidos por construtores e incorporadores contra seus clientes. No entanto esse sistema responde por menos de 10\% do volume total de crédito habitacional" (Coutinho; Nascimento, 2006, p. 146).

(24) O ciclo de crédito teve início em 2003, fortemente ancorado no crédito à pessoa física, e a expansão das operações de financiamento imobiliário, em 2006, seguindo o movimento de crescimento do crédito, em geral, e do consumo, em particular, com uma defasagem de dois anos, o que certamente denota a importância das medidas de incentivo institucionais para o discutido movimento. 
Tabela 1

Evolução do crédito total e habitacional no Brasil

\begin{tabular}{l|ccccc}
\hline & Crédito Total $^{1}$ & $\begin{array}{c}\text { Crédito } \\
\text { Habitacional }^{1}\end{array}$ & $\begin{array}{c}\text { Créd.Habitac./ } \\
\text { Crédito Total }\end{array}$ & $\begin{array}{c}\text { Créd.Habitac./ } \\
\text { PIB }\end{array}$ & $\begin{array}{c}\text { Crédito Total/ } \\
\text { PIB }\end{array}$ \\
\hline 2005 & 607.023 & 29.081 & $4,8 \%$ & $1,4 \%$ & $28,3 \%$ \\
2006 & 725.064 & 35.323 & $4,9 \%$ & $1,5 \%$ & $30,9 \%$ \\
2007 & 835.803 & 40.945 & $4,9 \%$ & $1,7 \%$ & $35,2 \%$ \\
2008 & 1.004 .569 & 51.786 & $5,2 \%$ & $2,1 \%$ & $40,5 \%$ \\
2009 & 1.174 .431 & 76.281 & $6,5 \%$ & $2,9 \%$ & $44,4 \%$ \\
2010 & 1.272 .742 & 103.541 & $8,1 \%$ & $3,8 \%$ & $46,4 \%$ \\
\hline $2005 / 2008$ & $65,5 \%$ & $78,1 \%$ & & & \\
$2008 / 2010$ & $26,7 \%$ & $99,9 \%$ & & & \\
$2005 / 2010$ & $109,7 \%$ & $256,0 \%$ & & & \\
\hline
\end{tabular}

Em milhões de reais de 2005 (deflacionados pelo IGP-DI).

Fonte: Banco Central do Brasil. Elaboração própria

Uma análise do movimento de financiamento imobiliário no Rio Grande do Norte no período em questão pode ser extraída da Tabela 2, que mostra a participação do Nordeste e do Rio Grande do Norte na concessão de crédito imobiliário no país ${ }^{25}$. Vale destacar que a natureza desses dados, que refletem os fluxos anuais de recursos, e não as alterações no estoque do período, é elucidativa, em especial quando considerados os elevados prazos dos financiamentos imobiliários.

Tabela 2

Evolução das concessões de crédito habitacional no Rio Grande do Norte (RN),

Nordeste (NE) e Brasil

\begin{tabular}{l|cccccc}
\hline & $\mathrm{RGN}^{1}$ & $\mathrm{NE}^{1}$ & Brasil $^{1}$ & RGN/NE & NE/Brasil & RGN/Brasil \\
\hline 2005 & 2,8 & 248,31 & $4.221,13$ & $1,1 \%$ & $5,9 \%$ & $0,1 \%$ \\
2006 & 41,4 & 632,31 & $9.218,08$ & $6,6 \%$ & $6,9 \%$ & $0,4 \%$ \\
2007 & 60,4 & $1.317,80$ & $13.390,66$ & $4,6 \%$ & $9,8 \%$ & $0,5 \%$ \\
2008 & 132,4 & $2.497,11$ & $24.562,54$ & $5,3 \%$ & $10,2 \%$ & $0,5 \%$ \\
2009 & 150,2 & $3.051,69$ & $28.237,20$ & $4,9 \%$ & $10,8 \%$ & $0,5 \%$ \\
2010 & 430,8 & $4.847,98$ & $41.775,90$ & $8,9 \%$ & $11,6 \%$ & $1,0 \%$ \\
\hline $2005 / 2008$ & $4642,3 \%$ & $905,7 \%$ & $481,9 \%$ & & & \\
$2008 / 2010$ & $257,0 \%$ & $113,0 \%$ & $86,6 \%$ & & & \\
$2005 / 2010$ & $20581,4 \%$ & $2516,9 \%$ & $1226,5 \%$ & & & \\
\hline
\end{tabular}

Em milhões de reais de 2005 (deflacionados pelo IGP-DI).

Fonte: Banco Central do Brasil. Elaboração própria

(25) No período analisado, os financiamentos imobiliários em Natal significavam cerca de $80 \%$ dos destinados ao Rio Grande do Norte. 
É certo que os anos observados e, sobretudo, o insignificante montante de concessões no Rio Grande do Norte no primeiro ano do período recomendam cautela na observação desses números ${ }^{26}$. No entanto, percebe-se que o ritmo de crescimento das concessões de crédito imobiliário foi muito mais intenso no Rio Grande do Norte em comparação com o Nordeste e, de forma mais ampla, com o Brasil, mesmo quando se considera a elevada expansão nestes últimos. Esse movimento se refletiu na elevação significativa da participação do Rio Grande do Norte no total das concessões, seja no Nordeste, seja no país. Dessa forma, percebe-se uma expansão do mercado de crédito imobiliário no Rio Grande do Norte, no período, se comparada a outros estados do Nordeste. Parece razoável, portanto, aferir que as mudanças operadas no financiamento imobiliário contribuíram para atrair instituições financeiras e tomadores de crédito habitacional no estado. No mesmo sentido, devem ser consideradas as inserções dos policy makers no mercado de crédito, sobretudo imobiliário. Ademais, é possível supor que o intenso movimento observado no mercado de crédito imobiliário do Rio Grande do Norte tenha implicado efeitos importantes no funcionamento do mercado imobiliário de Natal.

\section{Indicadores sobre o mercado imobiliário de Natal}

O objetivo deste item é construir indicadores que permitam avaliar se ocorreu um processo típico de formação de bolhas nos preços dos imóveis na cidade de Natal no período 2005-2007 e se houve algum tipo de reversão após a crise financeira de 2008. Durante o período, tornou-se comum, nos jornais da cidade, relatos sobre o aumento expressivo nos preços dos imóveis comercializados, não apenas em bairros onde se localizam as praias, mas também em outras áreas da cidade, com destaque para aquelas localizadas próximas à infraestrutura de serviços, como escolas e universidades, lazer, comércio e saúde.

Conforme destacado anteriormente, o período em questão pode ser subdividido em dois momentos: os triênios 2005-2007 e 2008-2010. O primeiro foi marcado pela formação de bolhas no mercado imobiliário em países centrais, com destaque para a economia norte-americana. Esse processo se desenvolveu em um contexto de grande permissividade financeira, em que a procura por rentabilidade esteve associada à ampliação de operações de crédito pouco seguras, como no caso do mercado de hipotecas subprime. O triênio 2008-2010 foi caracterizado pela

(26) Essa baixa participação pode ser melhor entendida quando se considera o PIB do Rio Grande do Norte em relação ao total do PIB do Nordeste e do Brasil no período 2005-2008 (considerando 2008 como o último ano com informações disponíveis). No referido período, a participação relativa do RN no PIB regional foi, em média, de $6,5 \%$, enquanto, para o Brasil, de $0,85 \%$. 
eclosão da crise financeira nos países centrais e seus desdobramentos ${ }^{27}$, entre os quais se destaca o arrefecimento das operações financeiras associadas ao mercado imobiliário. Uma posição de maior cautela refletiu-se, por exemplo, na diminuição da procura por novos destinos para aplicação de recursos, tendência observada nos dados apresentados no Gráfico 1.

No caso específico do Rio Grande do Norte, o relatório sobre ingresso de capitais estrangeiros registrados pelo Banco Central destaca que o investimento externo nos setores de turismo e imobiliário cresceu de maneira expressiva até 2008. (Observatório das Metrópoles, 2009). Esse aumento contribuiu para a expansão da oferta de meios de hospedagem e imóveis no estado, mais especificamente em Natal. Poder-se-ia argumentar que essa expansão esteve associada aos crescentes investimentos para a melhoria das atividades ligadas ao turismo no país como um todo, por um lado, e à expansão da oferta em resposta à demanda por habitação, por outro.

De fato, no período 2005-2007, não se pode negligenciar a importância dos projetos de melhoria na infraestrutura turística como fator de atração de novos investimentos no setor imobiliário, principalmente se considerarmos a proximidade de Natal com países desenvolvidos, destacadamente a Europa. Contudo, chama a atenção o fato de que a oferta de novos empreendimentos imobiliários tenha sido acompanhada por uma elevação substancial dos preços, o que denota indícios de formação de bolha nos preços do mercado imobiliário local.

Por outro lado, sem nos determos momentaneamente na presença estrangeira no mercado imobiliário, representantes do setor costumam citar o argumento de que os preços na cidade de Natal, no período analisado, estavam em elevação em decorrência da demanda por novos empreendimentos, alegando que, por razões jurídicas, ambientais e financeiras, a construção de novos imóveis não teria acompanhado a potencial procura ao longo dos anos 1990. A demanda reprimida durante aquele período, de proporções até então desconhecidas, teria se manifestado com a ampliação do volume de crédito destinado à habitação e melhoria das condições de financiamento.

Todavia, a comparação das características dos novos empreendimentos lançados em Natal em termos de área do imóvel, localização e preço com o perfil do déficit habitacional no estado por renda, conforme o Ministério das Cidades $^{28}$, explicita uma nítida incompatibilidade de perfis, uma vez que o déficit

(27) Uma discussão detalhada sobre todos os desdobramentos da crise financeira internacional fugiria aos objetivos deste trabalho. Restringiremos, portanto, a questão aos impactos no mercado imobiliário do Estado do Rio Grande do Norte.

(28) "Déficit habitacional no Brasil 2006", disponível em http://www.cidades.gov.br/secretariasnacionais/secretaria-de-habitacao/biblioteca/publicacoes-e-artigos/Deficit\%20-\%202006\%2006-05-2008.pdf/view. Acesso em: 25 ago. 2009. 
habitacional tem se concentrado em famílias com renda de até 3 salários mínimos para as quais a solução do problema reside em programas governamentais específicos, como a construção de casas populares.

\section{Gráfico 2}

Evolução dos preços dos imóveis prontos em Natal, variação do custo da construção civil e do IGP-M $(2005-2010 \%)$

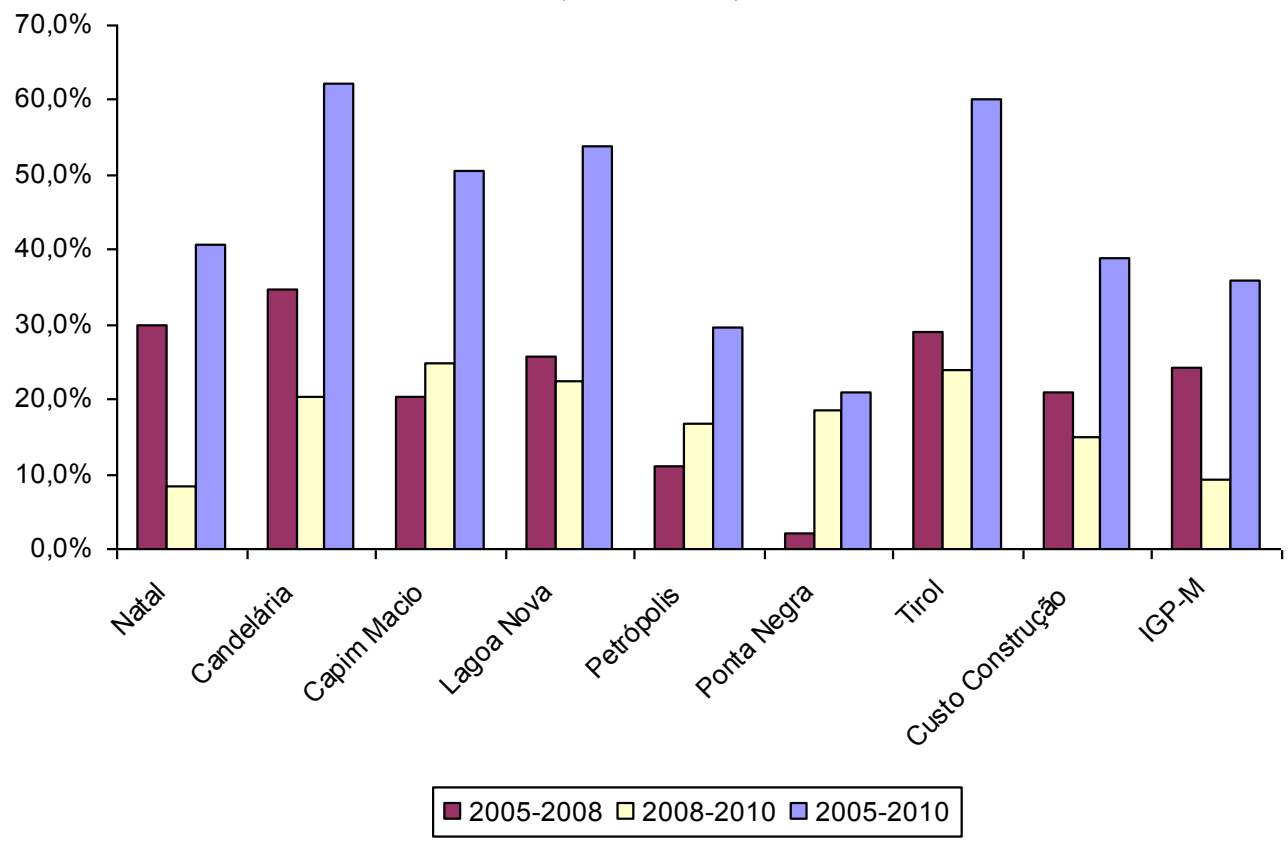

Fonte: Jornais locais. Elaboração própria.

A variável que mais se destaca em termos de existência de uma possível bolha especulativa é a evolução dos preços dos imóveis, com especial atenção para os imóveis já prontos. Ao longo do período em análise, conforme o Gráfico 2, a variação de preços dos imóveis foi marcante, considerando-se principalmente os dados por bairro. Em geral, a variação de preços superou o custo da construção e a inflação medida pelo IGP-M. Particularmente no bairro de Ponta Negra, a variação de preços foi menor, embora o preço por $\mathrm{m}^{2}$ já tivesse atingido valores substanciais no início do período. Conforme se verá nos demais indicadores, a atividade especulativa imobiliária tornou-se mais evidente nesse bairro.

O Gráfico 2 apresenta a variação de preço dos imóveis em dois subperíodos: 2005-2008 e 2008-2010. No primeiro, observa-se intenso processo de elevação de preços em Natal em praticamente todos os bairros. Deve-se destacar que, após 2008, mesmo com a eclosão da crise financeira internacional e a redução no ingresso de capitais estrangeiros no Rio Grande do Norte, a variação de preço dos imóveis tendeu a superar a variação do custo da construção civil. Ademais, 
houve continuidade no lançamento de novos empreendimentos em toda a cidade, inclusive com a entrada de incorporadoras que atuavam em outros centros do Brasil.

Para avaliar mais precisamente a existência de bolhas, foram construídos indicadores que levam em conta o comportamento dos preços dos imóveis prontos (preço spot), vendidos na planta (preço forward) e aluguéis, além da evolução do custo da construção civil em Natal e da Taxa Selic, como taxa de juros de referência. Abaixo, são detalhados os indicadores, bem como as variáveis utilizadas:

Indicador de preço dos imóveis (IP):

$$
I P=\frac{(\text { preçoimóvel pronto }- \text { preçoimóvel planta })}{\text { preço imóvel planta }}
$$

O indicador de preço IP será comparado com a taxa Selic. As empresas da construção civil comparam esse diferencial com a taxa de juros de referência para avaliar se compensa vender o imóvel na planta ou pronto. Deve-se ressaltar que o diferencial de preço a favor do imóvel pronto é um indicador de atratividade para novas construções. Quando essa diferença é substancial, pode haver indícios de movimentos especulativos.

Indicador de aluguel e preço (IA):

$$
I A=\frac{\text { aluguel }}{\text { preço imóvel pronto }}
$$

O indicador IA visa captar a ocorrência de descasamento de preços decorrente de um movimento de formação de bolhas nos preços dos imóveis. Em condições normais de operação do mercado imobiliário, o valor dos aluguéis tende a ser uma fração constante do preço dos imóveis. Na eventual presença de bolhas especulativas, o preço dos imóveis tende a aumentar mais que proporcionalmente quando comparado ao aluguel, causando redução no valor do índice IA. É possível comparar a evolução desse indicador com a da taxa de juros, de modo que reduções no IA maiores que eventuais reduções nos juros indicam movimento especulativo.

Indicador de preço e custo da construção (IC):

$$
I C=\frac{\text { preço imóveis }}{\text { custo construçãocivil }}
$$

O indicador IC fornece uma medida aproximada do " $q$ " de Tobin do setor de construção civil que, em linhas gerais, relaciona o valor de mercado de uma empresa e o custo de reposição de seus ativos. Valores acima de 1 indicam geração de lucro, assim como aqueles muito superiores a 1 podem indicar movimentos 
especulativos. Raciocinando em termos do modelo minskyano, podemos captar movimentos de descasamento acentuado entre os preços de oferta e demanda dos ativos imobiliários.

Os indicadores cobrem o período 2005-2010, sendo calculados também por bairro. Os bairros selecionados seguiram o critério de representatividade estatística na amostra, bem como a dinâmica do mercado imobiliário de Natal. Nesse sentido, optou-se por destacar bairros com maior número de empreendimentos imobiliários lançados no período e que estavam associados a algum fator de atração especial, como, por exemplo, infraestrutura turística e de serviços.

Destacam-se, por essas características, os bairros de Ponta Negra (em que se situa a principal praia de Natal e local de grande visibilidade junto a estrangeiros, concentrando a maioria dos equipamentos turísticos de apoio do município), Capim Macio, Lagoa Nova e Candelária (que, além da proximidade com Ponta Negra, representam o eixo de modernização, expansão comercial e de serviços da cidade, contando com shopping centers, supermercados, universidades e hospitais, entre outros), Tirol e Petrópolis (bairros nobres tradicionais, em que predominam imóveis de grande porte, e que, no entanto, se ressentiram com o lançamento de empreendimentos de maior liquidez comercial, ou seja, apartamentos de tamanho médio em torno de $100 \mathrm{~m}^{2}$ a $150 \mathrm{~m}^{2}$ ). Deve-se, ainda, destacar a importância de outros bairros, como Nova Parnamirim (fronteira de expansão de imóveis de classe média e média baixa da cidade, em que pese a localização no município vizinho), Lagoa Seca e Barro Vermelho. Não foram incluídos na amostra imóveis localizados nas regiões periféricas do município, considerando suas características de comercialização menos sujeitas a movimentos especulativos nos termos considerados neste trabalho.

As variáveis utilizadas foram:

Preço dos imóveis na planta (medido em R\$ e $\mathbf{R} \mathbf{\$} / \mathbf{m}^{2}$ ): informações coletadas junto ao setor imobiliário, compreendendo 101 empreendimentos lançados no período em questão.

Preço dos imóveis prontos (medido em $\mathbf{R} \mathbf{\$}$ e $\mathbf{R} \$ \mathbf{m} \mathbf{m}^{2}$ ): parte dos imóveis prontos compõe a mesma base de dados referente ao preço dos imóveis na planta, correspondendo aos imóveis cuja obra foi finalizada durante o período. Os preços dos demais imóveis foram coletados junto aos arquivos de classificados do Jornal Tribuna do Norte ${ }^{29}$, principal jornal em termos de circulação e anúncios na cidade. Os preços foram levantados nos finais de semana, quando a quantidade de imóveis

(29) Optou-se por restringir a análise a apenas um jornal, uma vez que as demais publicações, de menor porte, ofereciam menos anúncios ou então os já divulgados no Jornal Tribuna do Norte. 
anunciados é maior, dos meses de abril, outubro e dezembro dos anos em estudo. No total, foram coletados 2600 preços.

Aluguel (medido em R\$): informações obtidas junto aos arquivos de classificados do Jornal Tribuna do Norte. Os valores referentes a aluguéis foram coletados nos finais de semana dos meses de abril, outubro e dezembro dos anos em estudo. Foram analisados, no total, valores de 2200 aluguéis.

Taxa Selic (\% a.a.): coletada junto ao Banco Central do Brasil. Utilizou-se a média anual para comparação com o indicador de preço dos imóveis (IP).

Custo da construção civil em Natal (medido em $\mathbf{R} \mathbf{\$} / \mathbf{m}^{2}$ ): informações coletadas na Caixa Econômica Federal no âmbito da pesquisa do Sistema Nacional de Pesquisa de Custos e Índices da Construção Civil. Os valores anuais foram obtidos através da média dos valores mensais.

Nos indicadores IP e IC, utilizou-se o preço por $\mathrm{m}^{2}$ dos imóveis. No indicador IA, a compatibilização foi realizada por meio do preço do imóvel e do número de dormitórios, visto que pouquíssimos imóveis disponíveis para aluguel têm sua área anunciada nos classificados. Deve-se destacar que os valores dos indicadores para a cidade de Natal comportam todos os bairros presentes na amostra, mesmo quando, para determinada variável, o bairro não é destacado individualmente.

A seguir, são apresentados os indicadores por meio de tabelas e gráficos.

Tabela 3

Indicador IP e taxa Selic

\begin{tabular}{cccccccc}
\hline IP & Natal & Candelária & $\begin{array}{c}\text { Capim } \\
\text { Macio }\end{array}$ & $\begin{array}{c}\text { Lagoa } \\
\text { Nova }\end{array}$ & $\begin{array}{c}\text { Ponta } \\
\text { Negra }\end{array}$ & Tirol & $\begin{array}{l}\text { Taxa } \\
\text { Selic }\end{array}$ \\
\hline 2005 & $-0,101$ & $\mathrm{n} / \mathrm{d}$ & 0,187 & 0,120 & 0,209 & $-0,225$ & 0,191 \\
2006 & 0,180 & 0,125 & 0,188 & 0,061 & 0,116 & 0,058 & 0,153 \\
2007 & 0,159 & 0,476 & 0,007 & 0,078 & 0,313 & 0,072 & 0,120 \\
2008 & 0,218 & 0,135 & 0,107 & 0,212 & 0,085 & $-0,106$ & 0,124 \\
2009 & $-0,174$ & $\mathrm{n} / \mathrm{d}$ & $-0,177$ & $-0,257$ & $-0,311$ & 0,231 & 0,097 \\
2010 & $-0,161$ & $\mathrm{n} / \mathrm{d}$ & $-0,207$ & $-0,126$ & $-0,375$ & 0,064 & 0,098 \\
\hline
\end{tabular}

Fonte: Elaboração própria. $\mathrm{n} / \mathrm{d}$ : dados insuficientes para construir indicador significativo para o ano de referência.

Conforme argumentado inicialmente, os valores do indicador IP positivos indicam potencial atrativo para novas construções. Comparando os valores do indicador com a taxa Selic (última coluna da Tabela 3), observa-se que, no período 2005-2008, enquanto esta última manteve tendência de queda, o indicador IP evoluiu ascendentemente tanto para o total da cidade como para a maioria dos bairros. Em relação ao primeiro ano da série, apenas Ponta Negra e Capim Macio, 
bairros com elevado potencial de atração para novos investimentos, apresentaram valor de IP que sugere atratividade para novas construções. Esse comportamento decorreu, provavelmente, de empreendimentos localizados, já indicando movimento especulativo.

No do bairro de Tirol, conforme destacado, havia muitos imóveis antigos e de grande porte, com poucos lançamentos anteriores a 2007. Isso fez com que o valor por $\mathrm{m}^{2}$ se tornasse mais baixo para os imóveis prontos devido ao maior número de usados em comparação com os novos prontos. Não se deve descartar, também, a hipótese de que, entre os imóveis anunciados nos jornais, houvesse concentração de imóveis antigos com preço por $\mathrm{m}^{2}$ reduzido para esse bairro. Porém, se de fato essa era a característica do mercado na região, há indícios substanciais de elevação dos preços para os demais anos, com indicador positivo a partir de 2006.

Para Natal, observa-se comportamento semelhante no primeiro ano da série, provavelmente pelas mesmas razões apontadas acima. A atratividade de novas construções aumentou durante o período, superando a taxa Selic em praticamente todos os bairros entre 2006 e 2008. O aumento dos preços dos imóveis provavelmente ocorreu de forma generalizada, inicialmente a partir dos bairros valorizados para então se expandir em direção aos demais. Deve-se ressaltar que essa tendência segue em direção a bairros periféricos da cidade. Com a construção da nova ligação de Natal com a Zona Norte do município, inaugurada em 2007, bairros que historicamente não despertavam interesse imobiliário passaram a contar com novos lançamentos de empreendimentos e valorização dos imóveis já existentes.

No período posterior a 2008, o indicador IP tornou-se sistematicamente negativo. Esse resultado sugere que os preços dos imóveis prontos foram superados pelos preços dos imóveis na planta. Nesse mesmo período, a taxa Selic seguiu sua trajetória descendente, ou seja, os preços dos novos empreendimentos mantiveram uma trajetória de crescimento, enquanto os imóveis prontos se valorizaram com menor intensidade. Convém observar que, nesse período, os indicadores econômicos mantiveram bom desempenho, especialmente se considerarmos emprego, renda e expansão do crédito imobiliário.

Esse comportamento do indicador IP, analisado em conjunto com as informações do Gráfico 1, aponta redução, mas não estancamento no ingresso de capitais estrangeiros (cumpre destacar que os ingressos destinados ao setor de turismo e imobiliário mantiveram sua importância relativa). O Gráfico 2 indica a persistente alta de preços, embora em menor proporção após 2008, sugerindo um descolamento dos preços dos imóveis prontos. Revela, portanto, uma mudança nos 
preços relativos em que, a despeito da continuidade do aumento de preços nos dois mercados no biênio 2009-2010, o preço forward passou a superar o preço spot.

Gráfico 3

Indicador IA (aluguel e preço)

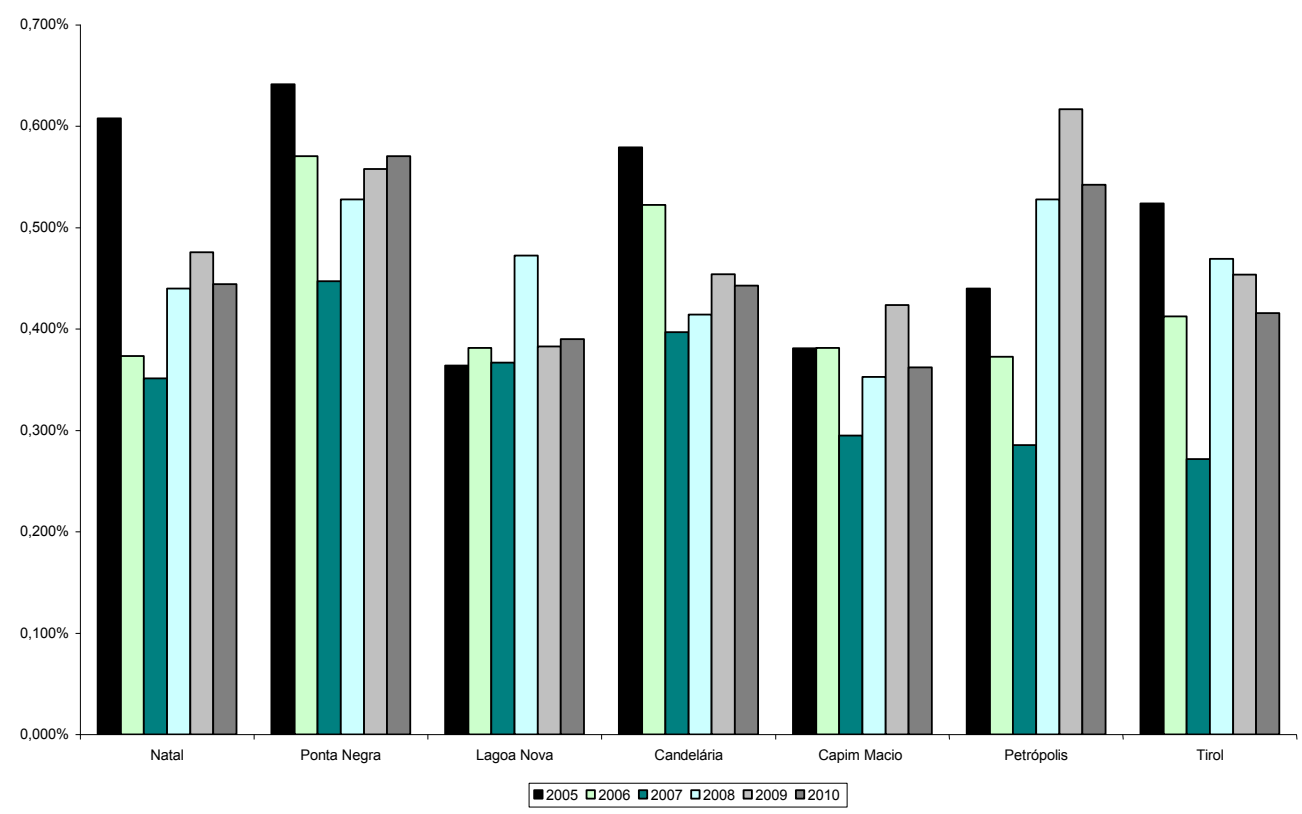

Fonte: Elaboração própria.

No caso do indicador IA, conforme o gráfico acima, é possível observar a redução generalizada do valor ao longo do período 2005-2007, à exceção do bairro Lagoa Nova, que se manteve estável. Observa-se que ocorre convergência para valores de aluguéis situados entre $0,3 \%$ e $0,4 \%$ do preço do imóvel e que, após 2008 , apesar da recuperação do valor dos aluguéis, o patamar de preços de locação vigentes no início do período não é atingido, isto é, os aluguéis não acompanharam plenamente a evolução dos preços de venda. Em termos comparativos, considera-se a faixa de $0,6 \%$ a $1 \%$ do valor do imóvel como base para aluguéis nas grandes cidades brasileiras, dependendo das condições de conservação e negociação. Se os aluguéis acompanham plenamente a evolução dos preços, em um eventual contexto especulativo, podem se tornar altos demais, acarretando o comprometimento da renda de possíveis inquilinos.

Adicionalmente, como mostrado no Gráfico 2, a variação dos preços dos imóveis em Natal foi superior à variação do IGP-M, principal índice de reajuste dos aluguéis. O comportamento do indicador IA sugere a existência de uma defasagem entre os valores dos aluguéis e preços, sintoma de formação de bolhas especulativas. Observa-se, pelo gráfico, que o valor do aluguel como proporção do 
preço do imóvel em 2007 representava pouco mais da metade se comparado a 2005 na cidade de Natal (de $0,61 \%$ para $0,35 \%$ ), assim como na maioria dos bairros. Em 2010, essa proporção ainda estava, de maneira geral, abaixo de $0,5 \%$. Comparando-se essa evolução com o comportamento da taxa Selic, apresentado na Tabela 3, verifica-se que a queda no IA é mais acentuada, em que pese a redução observada nos juros nesse período. Pode-se, portanto, concluir que tanto o indicador IP como o indicador IA sugerem a existência de bolha no mercado imobiliário de Natal.

Já o indicador de preço e custo da construção, medida aproximada do "q" de Tobin do mercado de construção civil de Natal, situou-se em valores superiores a 1, conforme os dados da Tabela 4. Considerando que valores do "Q" de Tobin acima de 1 indicam um possível boom no mercado, valores muito superiores a 1 e com tendência prolongada de alta são indicadores de bolha especulativa. Os valores observados para o bairro de Ponta Negra fornecem uma dimensão do ritmo de descasamento entre preços e custos, visto que o bairro se consolidou como o principal foco do movimento especulativo nos preços dos ativos imobiliários.

Tabela 4

Indicador IC

\begin{tabular}{cccccccc}
\hline IC & Natal & Candelária & $\begin{array}{c}\text { Capim } \\
\text { Macio }\end{array}$ & $\begin{array}{c}\text { Lagoa } \\
\text { Nova }\end{array}$ & Petrópolis & $\begin{array}{r}\text { Ponta } \\
\text { Negra }\end{array}$ & Tirol \\
\hline 2005 & 4,1 & 3,7 & 4,5 & 4,4 & 4,5 & 7,1 & 3,4 \\
2006 & 4,4 & 3,7 & 3,9 & 3,3 & 3,5 & 5,6 & 3,6 \\
2007 & 4,7 & 4,5 & 5,1 & 4,6 & 4,3 & 7,0 & 4,8 \\
2008 & 5,1 & 4,9 & 4,3 & 4,7 & 4,1 & 5,6 & 3,9 \\
2009 & 3,7 & 3,6 & 4,0 & 3,7 & 3,2 & 4,6 & 4,4 \\
2010 & 4,0 & 4,6 & 3,9 & 4,3 & 3,9 & 4,3 & 4,6 \\
\hline
\end{tabular}

Fonte: Elaboração própria.

Se colocarmos a questão em termos da análise minskyana, o movimento de aumento relativo dos preços dos imóveis prontos em relação ao custo base da construção civil verificado nesse período indica um descasamento acentuado entre os preços de oferta e demanda dos ativos imobiliários, corroborando a tese de que existe a presença de uma bolha especulativa no setor. Essa tendência se mantém durante todo o período 2005-2010, sugerindo que, apesar do arrefecimento após 2008, a alta dos preços dos imóveis parece indicar que não houve implosão da bolha imobiliária da cidade.

\section{Considerações finais}

A primeira seção procurou recuperar alguns dos modelos de formação de preços de ativos que pudessem elucidar o fenômeno da geração de bolhas, 
especificamente de bolhas imobiliárias. A segunda seção visou aplicar essas considerações teóricas ao estudo da bolha de imóveis em Natal. O tratamento dos dados da terceira seção permitiu a elaboração de indicadores a partir dos quais foram verificados fortes indícios de ocorrência de bolha nos preços dos imóveis em Natal no período 2005-2007 e de que a crise de 2008 não provocou sua implosão no biênio 2009-2010. Os capitais oriundos do exterior provavelmente contribuíram para a formação e sustentação da bolha, estimulando a valorização acentuada dos preços dos ativos imobiliários no primeiro triênio. Ademais, no período 2005-2007, cresceram também os recursos oriundos do SBPE voltados para o financiamento habitacional.

Esse movimento de preços dos ativos imobiliários não se restringiu a Natal, sendo notado em outras capitais e cidades de maior porte no país, bem como no exterior. Mas, em se tratando daquele município, a bolha parece ter assumido uma configuração tal como a descrita no modelo de Dymsky (1998), com o influxo de capital externo à região assumindo papel decisivo em sua geração. Não se pode ainda desconsiderar a hipótese de que a expectativa de valorização dos imóveis tenha atraído parte da população nativa, contribuindo para sustentar a demanda elevada dos mesmos e contaminando os preços no mercado secundário.

Os riscos relacionados à formação de bolhas são conhecidos e tratados à exaustão na literatura. Mudanças nas expectativas em relação à viabilidade de realização de lucros com novos empreendimentos podem induzir movimentos de reversão brusca de posições de modo a fragilizar os agentes envolvidos no mercado imobiliário e demais conexões financeiras, conforme observado em países que vivenciaram situações semelhantes.

Evidentemente, as consequências desse processo dependem do grau de risco envolvido nas posições tomadas pelos agentes, diretamente associadas às expectativas e às condições de financiamento, bem como do comportamento da demanda por ativos imobiliários. Por outro lado, do ponto de vista de alguns daqueles que simplesmente desejam adquirir um imóvel para fins de moradia, enquanto persistir a bolha, o preço do almejado bem permanecerá proibitivo.

Nesse sentido, o trabalho procurou examinar os efeitos da crise no mercado de imóveis local que se seguiram ao transbordamento da crise financeira de 2008 e atingiram as economias dos países de origem de turistas com destino à Natal, além da própria economia brasileira. Os dados mostram uma redução do número de turistas internacionais que visitaram a cidade após esse período, bem como do fluxo de capital externo dirigido à compra de imóveis. Ademais, conforme ressaltado, a crise assolou o sistema de crédito brasileiro em um período caracterizado pela expansão significativa de suas operações, embora enfrentada por uma política contracíclica pelos bancos públicos federais que compensou a 
redução da oferta de crédito privado, assegurando inclusive o aumento do financiamento imobiliário no período. Os dados acerca da participação relativa do Rio Grande do Norte na concessão de crédito habitacional no país revelam uma tendência de crescimento no período analisado, passando de $0,5 \%$ para $1,0 \%$ entre 2008 e 2010, concentrando, em Natal, cerca de $80 \%$ dos recursos emprestados.

O aumento do crédito habitacional após 2008 parece ser uma das causas explicativas para a manutenção do crescimento dos preços dos imóveis na cidade a despeito da redução do influxo de capital estrangeiro para a aquisição de ativos imobiliários. Todavia, há alguns aspectos que precisam ser considerados: o indicador de preço dos imóveis (IP), que, em 2008, atingiu o pico de 0,218, em 2009 e 2010 tornou-se negativo, ou seja, $-0,174$ e $-0,161$, respectivamente. A mudança de preços relativos que responde pela redução desse indicador nesses dois últimos anos, se não sinaliza uma queda de demanda, já que tanto o preço forward (preço do imóvel na planta) quanto o preço spot (preço do imóvel pronto) continuaram a subir, parece indicar um arrefecimento no ritmo de incremento dos preços.

É importante observar que o preço spot é sensível à variação de demanda, sendo resultante de uma curva de oferta preço inelástica que incorpora exclusivamente os estoques de imóveis herdados de períodos anteriores, e não os recentemente produzidos. Já, o preço forward resulta de uma função de oferta preço elástica, consistindo, portanto, em um preço no qual a incorporadora estabelece um mark up sobre o custo da construção.

A partir dos dados empíricos expostos na seção anterior e à luz do tratamento teórico desenvolvido por Davidson (1978, p. 88), é possível observar que, no biênio 2009-2010, ocorreu uma situação de contango no mercado imobiliário de Natal. Considerando que ambos os preços subiram, mas a taxas diferenciadas, a única explicação plausível parece ser a de que esse fenômeno tenha sido gerado pelo aumento do custo da construção civil (vide Gráfico 2), mais rápido, portanto, que o incremento da demanda, implicando a elevação do preço forward em um ritmo superior ao preço spot: a situação de contango, nesse caso, parece indicar que a elevação do preço dos imóveis prontos não pôde acompanhar a subida dos custos de produção dos novos imóveis, pois a intensidade do aumento da demanda em face de um estoque maior de apartamentos recém-construídos não o permitiu.

A situação de contango descrita por Davidson expressa tipicamente uma redundância de ativos. Mas o mercado imobiliário de Natal no biênio acima aludido corresponde ao fenômeno no qual existe produção de novos ativos (construção de apartamentos). Assim, deve ser ressaltado que a redundância de estoques deve ser qualificada como relativa (contango tipo 1 de Davidson). 
Convém ainda ressaltar que o comportamento dos demais indicadores Aluguel e Preço (IA) e Preço e Construção (IP) - ainda não aponta para a implosão da bolha imobiliária em Natal no período 2009-2010. Contudo, se o fenômeno de crescimento dos custos de construção superior ao da demanda se mantiver nos próximos anos, de modo a gerar uma situação na qual o preço spot caia abaixo do preço mínimo que induza novas construções (contango tipo 2 de Davidson), tenderá a provocar implosão, desestimulando a produção de imóveis verticais na cidade.

\section{Referências bibliográficas}

ANDERSON, P.; ARROW, K.; PINES, D. (Org.). The economy is an evolving complex system. Redwood City: Addison Wesley, 1988.

BLACK, J. Oxford dictionary of economics. Oxford University Press, 1997.

BLANCHARD, O. J.; FISCHER, S. Lectures in macroeconomics. NewYork: MIT Press, 1989.

CANUTO, O.; LAPLANE, M. Especulação e instabilidade na globalização financeira. Economia e Sociedade, Campinas, n. 5, p. 31-60, dez. 1995.

CARVALHO, F. J. C. Sobre a preferência pela liquidez dos bancos. In: AMADO, A. et al. Sistema financeiro: uma análise do setor bancário brasileiro. Elsevier, 2007.

COUTINHO, L. M.; NASCIMENTO M. M. Crédito habitacional acelera o investimento habitacional no país. In: TORRES FILHO, E. T.; PUGA, F. P.; FERREIRA, F. M. R. (Org.). Visão do desenvolvimento. Rio de Janeiro: BNDES, 2006.

DAVIDSON, P. [1972]. Money and the real world. 2. ed. Basingstoke: MacMillan, 1978.

DYMSKI, G. A. "Economia de bolha" e crise financeira no leste asiático e na Califórnia: uma perspectiva espacializada de Minsky. Economia e Sociedade, Campinas, n. 11, dez. 1998.

. Bolhas de ativos e crises em Minsky: uma abordagem espacializada. In:

FERRARI FILHO, F.; Paula, L. F. (Org.). Globalização financeira: ensaios de macroeconomia aberta. Petrópolis, RJ: Vozes, 2004.

FERREIRA, A. L. et al. Dinâmica imobiliária, turismo e meio ambiente: novos cenários metropolitanos In: CLEMENTINO, M. L. M.; ZORAIDE, P. (Org.). Natal, uma metrópole em formação. Educ, 2009.

JORNAL TRIBUNA DO NORTE, 28 jan. 2007.

JORNAL TRIBUNA DO NORTE, 23 ago. 2008.

HAUGEN, R. A. The inefficient stock market. New Jersey: Prentice-Hall, 1999.

HICKS, J. R. Value and capital. Oxford: Oxford University Press, 1939. 
KEYNES, J. M. (1936). A teoria geral do emprego, do juro e da moeda. São Paulo: Abril Cultural, 1982. (Coleção Os Economistas).

KINDLEBERGER, C. P. Manias, panics and crashes: a history of financial crises. New York: Basic Books, 1978. Edição revisada, 1989. Tradução para português: Manias, pânico e crashes: um histórico das crises financeiras. Rio de Janeiro: Nova Fronteira, 2000.

MACEDO E SILVA, A. C. A montanha em movimento: uma notícia sobre as transformações recentes da economia global. In: CARNEIRO, R. (Org.). A supremacia dos mercados e a política econômica do governo Lula. São Paulo: Editora Unesp, 2006.

A macroeconomia sem equilibrio. Petrópolis: Vozes; Campinas, SP: Fecamp, 1999.

MANDELBROT, B. B. Fractals and scaling in finance: discontinuity, concentration, risk. New York: Springer Verlag, 1997.

MILES, D.; SCOTT, A. Macroeconomia: compreendendo a riqueza das nações. Editora Saraiva, 2005.

OREIRO, J. L Bolhas, incerteza e fragilidade financeira In: Globalização financeira: ensaios de macroeconomia aberta. In: FERRARI FILHO, F.; Paula, L. F. (Org.). Globalização financeira: ensaios de macroeconomia aberta. Petrópolis, RJ: Vozes, 2004.

OBSERVATÓRIO DAS METRÓPOLES - NÚCLEO NATAL. Estudo comparativo sobre o papel das atividades imobiliária-turísticas na transformação do espaço social das metrópoles nordestinas: Salvador, Recife, Natal e Fortaleza. Natal: UFRN, 2009. (Relatório de Pesquisa - Preliminar).

RIBEIRO, L. C. Q. Dos cortiços aos condomínios fechados: as formas de produção da moradia na cidade do Rio de Janeiro. Rio de Janeiro: Civilização Brasileira e Ippur (UFRJ), 1997.

SANTOS, H. L. A Atividade turística e o setor imobiliário: influxos de riqueza e trabalho em Natal. Monografia. Universidade Federal do Rio Grande do Norte, Natal, 2007.

SECRETARIA DE TURISMO DO RIO GRANDE DO NORTE: indicadores básicos de turismo. Natal, 2007.

TOBIN, J. A general equilibrium approach to monetary theory. Journal of Money, Credit and Banking, 1, p. 15-29, 1969.

VIDOTTO, C. O espectro de Keynes ronda a América: hipotecas, securitização e crise financeira nos Estados Unidos. In: SICSÚ, J.; VIDOTTO, C. (Org.). Economia do desenvolvimento. Rio de Janeiro: Elsevier, 2008. 